\title{
Contents Vol. 15, 1955
}

Borderland of Neurology — Grenzgebiete der Neurologie Les Confins de la Neurologie

L. Alexander. Boston, Miss. A. AuStregesilo, Rio de Janeiro

A. BARre, Sjasbourg M. BEndER, New York R. BING, Basel

G. BODBCHTEL, München L. VAN BOGAERT, Anvere T. BROMAN, Göteborg

A. BRÜCKNER, Basel H. BRUNNER, Newark, N.J.

H. CAIRNS, London

P. CoKKALIS, Athen

P. DBLMAS-MARSALET, Bordeaux

TH. DeMETRIADES, Athen

TSMPLE FAT, Philadelphia, Fa.

J. F. FUXTON, New Haren, Conn.

A. FRANCESCHETTI

Geneve 
COLLABORATORES:

F. GEORGI, Basel

L. HALPERN, Jerusalem

A. HAUTANT, Paris

G. HoLMBS, London

B. HORANYI, Budapest

L. VAN DER HORST, Amsterdam

J. IGERSHEIMER, New York

W. KJLESTADT, New York

A. KNAPP, New York

K. KRABBE, Kopenhagen

H. KOHLENBECK, Philadelphia, Pa.

F. LBIRI, Helsinki

R. LERICHE, Strasbourg

J. LHERMITTE, Paris

REDACTORBS: A. R. JBNTZER

Geneve 
R. LORENTB DB N6, New York

E. LUDWIG, Basel

D. J. MCCARTHY, Philadelphia, Pa.

G. H. MONRAD-KROHN, Oslo

F. NAVTLLE, Geneve

C. NYLEN, Uppsala

I. OLNINCK, New York

K. ORZECHOWSKI, Warazawa

T. J. PUTNAM, Los Angeles, Cal

E. RüTISHAUSER, Geneve

E. SACHS, New Haven, Conn.

A. SCHÜLLER, Melbourne

J. STAEHELIN, Basel

R. WARTENBERG, San Francisco, Cal P. H. WILCOX, Traverse City, Mich. H. T. WYCIS, Philadelphia, Pa.

E. B. STRBIFF

Lausanne

EDITOR: E. A. SPIEGEL (PHILADELPHIA)

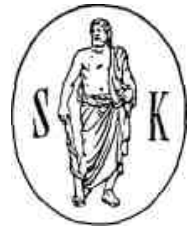

Vol. 15 
1955

BASEL (Schweiz)

S. KARGER

NEW YORK 


\section{INDEX}

Adler, E., J. Landau and E. Rabinowitz, Palsy of Conjugate Eye-Movements

in Poliomyelitis

Aprison, M. H., vide P. Nathan

Bärtschi-Rochaix, W.,wid. H. Sutermeister, Zur Pathophysiologie des Lachens,

zugleich ein Beitrag über licht-aktivierte Lachanfälle

Beck, $W$, vide A. Biemond

Benton, A. L., vide H. L. Blackburn

Beuthien, A., vide F. Georgi

Biemond, A., and W. Beck, Neural Muscle Atrophy with Degeneration of the

Substantia Nigra

- and J. JJ. M. Sinnege, Tabes of Friedreich with Degeneration of the Sub

stantia Nigra, a Special Type of Hereditary Parkinsonism.

Blackburn, H. L., and A. L. Benton, Simple and Choice Reaction Time in

Cerebral Disease

Blum, J.-D., vide A. Franceschetti

Bornstein, B, and P. Efrati, Encephalomyelitis due to Atypical Pneumonia

Brändle, K., Die posttraumatischen Opticus-Schädigungen (insbesondere die

Opticusatrophie)

Buffat, J.-D., Tumeurs intracraniennes et radiotherapie

Callagan, J. E., vide J. W. Lovett Doust '

Chiarugi, E., G. F. Rossi and A. Zanchetti, The Spinal Course of the Cortico-

fugal Fibers Arising in the Motor Cortex of the Cat

Davis, E., L. Holpern, L. Laszlo and 0. Heim, Effect of Electric Convulsive

Shock on Human Capillaries ...

Dekaban, A. S., Investigation into the Possible Infective Etiology of Multiple

Sclerosis

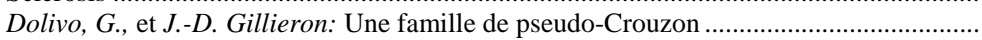

Dolivo, G., vide A. Franceschetti

Efrati, $P$., vide B. Bornstein

Escher, Fr., L'operation de l'otospongiose par voie retroauriculaire en deux

temps $>* \mathrm{JL}$

Fay, T., The Probable Origin and Purpose of the Superficial Reflex, Known as the Sign of Babinski...

Franceschetti, A., G. Maeder, G. Dolivo et J.-D. Blum, A propos de 3 cas de dystose cranio-faciale (Crouzon) JÄT"

Fitster de Carulla, J, Die Physiopathologie der Kataplexie

Georgi, F., und A. Beuthien, Multiple Sklerose. Pathogenetische Überlegun

gen und therapeutische Möglichkeiten ...................................Jk.

Gillieron, J.-D., vide G. Dolivo

Girardet, P.; A propos de trois observations de citerne interventriculaire 105

Gramberg-Danielsen, B., Zur histopathologischen Einordnung der primären

Opticustumoren 
Gumpertz, F., vide M. Streifler Holpern, L., vide E. Davis Heim, O., vide E.Davis Himwich, H. E., vide P. Nathan

- vide F. Rinaldi

Kaeser, E. H., Augensymptome bei der benignen blanden Sinusthrombose 162

—Einseitige Carotisthrombosen nach Strangulation

162

Kayser, R., Über infantile familiäre Opticusatrophie (Behr)......................................... 310

Keup, W., Zur Kenntnis der Eiweißkörper des Gehirns. Tiselius-elektro-

phoretische Untersuchungen.

Klein, D.: Etüde genetique et nosologique de l'idiotie amaurotique infantile 119

Landau, J., vide E. Adler

Laszlo, L., vide E. Davis

Lovett Doust, J, W., and J. E. Callagan, Studies on the Physiology of Aware-

ness: .Metabolie Concomitants of the Peremption of Colour

Maeder, G., vide A. Franceschetti

Montanari, $C$., vide $G$. Tonini

Müller, H. R., Über das Verhalten katatoner und nicht katatoner Formen

der Schizophrenie im Quick'schen Hippursäuretest

Nathan, P., M. H. Aprison and H. E. Himwich, A Comparison of the Effects

of Atropine with those of Several Central Nervous System Stimulants on

Rabbits Exhibiting Forced Circling Following the Intracarotid Injection

of Di-Isopropyl Fluorophosphate.

Rabinoivitz, E., vide E. Adler

de Reynier, J.-P.: Quelques reflexions sur la dysreflexie vestibulaire croisee 101

Ricci, A., et E. Rasselet, Uveite et paralysie faciale

Rinaldi, F., and H. E. Himwich, The Site of Action of Antiparkinson Drugs 209 Rochat, R.,

et $G$. Terrier, Considerations audiometriques ä propos d'un cas

de zona otique

Rasselet, E., et G., Syndrome de Romberg et manifestations oculaires.... 98

Rosselet, E., vide A. Ricci

Rosselet, G., vide E. Rosselet

Rossi, G. F., vide E. Chiarugi

Sinnege, J. L. M., vide A. Biemond

Streifler, M., and F. Gumpertz, Cerebral Potentials in Stuttering and Clutter-

ing.....

Sutermeister, H., vide W. Bärtschi-Rochaix

Terrier, G., vide R. Rochat

Tonini, G., and C. Montanari, Effects of Experimentally Induced Psychoses

on Artistic Expression

Zanchetti, A., vide E. Chiarugi

Preliminary Notes

Mautner, H., Combined Prostigmin-Ephedrine Treatment of Mentally

Retarded Children

Gesellschaftsberichte - Society Transactions - Societes

XlVe Reunion des Oto-Neuro-Ophtalmologistes et Neurochirurgiens romands.

La Chaux-de-Fonds, 16 et 17 octobre 1954

Buchbesprechungen - Book Reviews - Livreg Nonveaux ... 68, 128, 265, 323, 377

Varia

Personalia 